ARTICLE HISTORY: June: 17, 2021 Accepted: August 13, 2021 Published: August 19, 2021

УДК 622.807 .8

ПРОБЛЕМЫ БОРЬБЫ С ПЫЛЬЮ НА МОРСКИХ УГОЛЬНЫХ ТЕРМИНАЛАХ

Кожевникова Ольга Максимовна

специалист по охране труда отдела (службы)

охраны труда Правительства Приморского края

Россия, г. Владивосток

Московая Ирина Владимировна

Похил Полина Евгеньевна

аспиранты ДВФУ

Россия, г. Владивосток

\title{
PROBLEMS OF DUST CONTROL AT THE SEA COAL TERMINALS
}

\author{
Kozhevnikova Olga Maksimovna \\ specialist in labor protection \\ of the department (service) of labor protection \\ of the the Government of Primorsky Krai \\ Russia, Vladivostok \\ Moskovaya Irina Vladimirovna \\ Pohil Polina Evgenievna \\ FEFU graduate students \\ Russia, Vladivostok
}

Аннотация. В статье рассматривается вопрос о проблемах перевалки угля на морском угольном терминале, влиянии угольной пыли на организм человека и окружающую среду. Предложена установка аспирационного укрытия узла пересыпа конвейера с целью снижения концентрации угольной пыли в атмосферном воздухе.

Abstract. The article deals with the problems of transshipment of coal at the sea coal terminal, the impact of coal dust on the human body and the environment. To reduce the concentration of coal dust in the atmospheric air, it is proposed to install an aspiration shelter for the belt conveyor.

Ключевые слова: морской угольный терминал, процессы перевалки угля, угольная пыль, здоровье работающих, ленточный конвейер, аспирационное укрытие.

Keywords: sea coal terminal, coal transshipment processes, coal dust, workers health, belt conveyor, aspiration shelter.

Одним из важнейших топливно-энергетических ресурсов в мире, помимо газа и нефти, является угольная продукция. Россия, как по запасам угля, так и по его добычи, устойчиво занимает ведущую позицию в рейтинге угледобывающих стран, а также крупнейших экспортеров угля. Основными потребителями угля являются страны азиатско-тихоокеанского бассейна: Китай, Индия, Япония, Южная Корея и др.

Уголь, добываемый в Кузбассе, Якутии, Хакасии и других угольных бассейнах, поступает железнодорожным транспортом на морские угольные терминалы Дальневосточного региона для перевалки на морские суда. Значительная часть экспорта российского угля проходит через порты Приморского края: Находкинский, Владивостокский, Посьет. В заливе «Находка» располагаются более десяти морских угольных терминалов и только один специализированный на угольную продукцию - $\mathrm{AO}$ «Восточный Порт». На рисунке 1 изображен график динамики перевалки угля АО «Восточный Порт» за последние десять лет. 


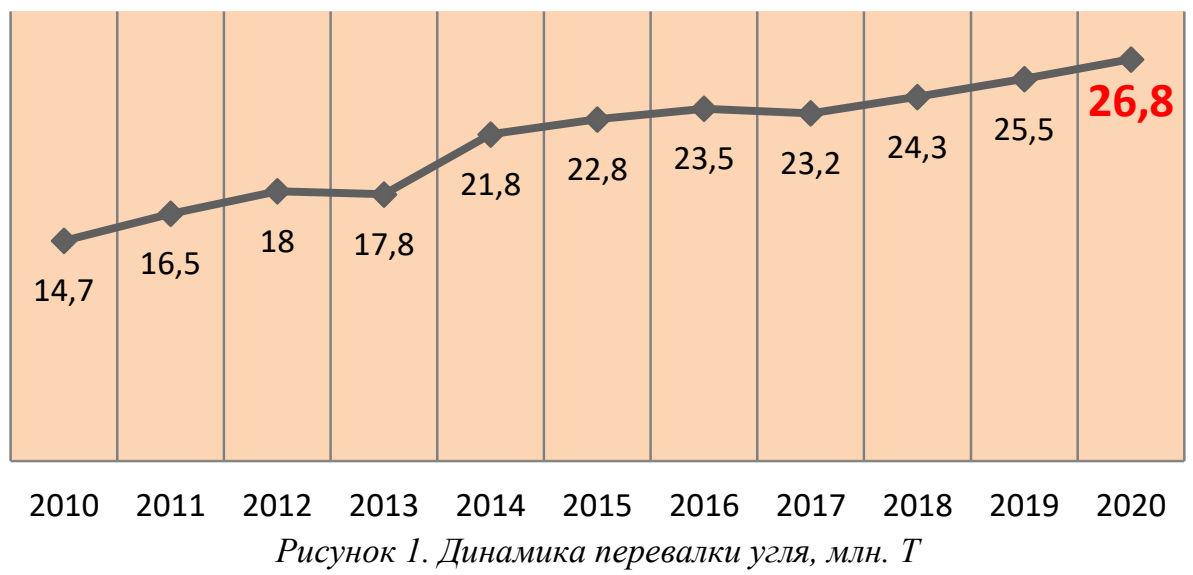

Как видно из рисунка 1, на сегодняшний день стивидорная компания АО «Восточный Порт» увеличила перевалку угля почти в два раза. В АО «Восточный Порт» реализован крупнейший проект по строительству третьей очереди специализированного угольного комплекса (ППК-3), что увеличит грузооборот до 50-55 млн тонн угля в год.

Терминал оснащен специализированным перегрузочным оборудованием, включающим: станцию разгрузки вагонов, состоящую из двух тандемных вагоноопрокидывателей, систему ленточных конвейеров, осуществляющих погрузку угля с вагонов как на судно, так и на склад; четыре судопогрузочные машины. На терминале имеется станция по разгрузке вагонов с двумя тандемными вагоноопрокидывателями. В среднем обрабатывается около 700 вагонов в сутки. Также в наличии 4 вагоноразмораживающих устройства (вмещают одновременно 80 полувагонов). Уровень автоматизации на ППК-3 достигает почти 99\%. Складские площади терминала позволяют хранить единовременно до 600 тысяч тонн угля. На складе ППК-3 функционируют 4 реклаймера и 2 стакера. Стакеры и реклаймеры используются для распределения груза на площадках хранения и отгрузки на ленточные конвейеры при погрузке угля на суда.

Это значит, что с увеличением грузооборота возрастет и количество угольной пыли, что негативно повлияет на состояние атмосферного воздуха, промышленных вод и морскую акваторию порта.

На морской терминал уголь поступает по железной дороге в вагонах и его перевалка может осуществляться двумя способами - грейферным способом или при помощи стакеров и реклаймеров. В первом случае угольная продукция извлекается из вагонов и поступает сразу на судно с помощью грейферного крана. Во втором случае уголь извлекается вагоноопрокидывателем, стакером на складе формируются штабели угля и реклаймером подается через судопогрузочный конвейер в трюм судна.

На морском угольном терминале на сегодняшний день остаётся актуальным вопрос борьбы с угольной пылью. Угольная пыль на морских терминалах образуется, в основном, при механическом воздействии на уголь, то есть, в процессе перегрузки, а также вследствие ветровой эрозии с открытых штабелей угля.

На территории порта, как правило, есть три наиболее крупных источника пыления, где происходят различные манипуляции с углем: при выгрузке его из вагонов, погрузке на судно, а также на пересыпных станциях при пересыпе с одного конвейера на другой.

Пыль, образующаяся в процессе транспортировки и хранения угля на открытых территориях, является одним из неблагоприятных факторов, оказывающих негативное влияние на организм работающего.

Вдыхание работником угольной пыли является причиной ряда профессиональных заболеваний органов дыхания. Наиболее опасными для человека считаются частицы размером 0,2-0,7 мкм, которые, попадая в легкие при дыхании, задерживаются и накапливаются в них. Повреждение частицами пыли слизистой оболочки дыхательных путей постепенно приводит к хроническому воспалению — пылевому бронхиту. Входящий в состав угольной пыли диоксид кремния $\mathrm{SiO}_{2}$, воздействуя на бакаловидные клетки, приводит к деформации бронхов, изменению физических свойств слизи и способствует дальнейшему развитию антракоза или силикоза [1].

Угольная пыль может также негативно воздействовать на кожу, может спровоцировать зуд и в крайних случаях дерматит. При закупорке пылью сальных желез может возникнуть популезная сыпь, а в случае присоединения вторичной инфекции - пиодермия.

При работе в запыленной атмосфере возможно заболевание глаз. Угольная пыль обладает сильным сенсибилизирующим действием на слизистую оболочку и роговицу глаза, вызывая при работе тяжелые конъюктивиты, сопровождающиеся отеком век [2].

Существует множество способов борьбы с угольной пылью в морских портах. Как правило, применяют следующие методы — орошение угольной пыли из водяных и снежных пушек, применение различных 
химических составов, установка веторозащитных экранов. Но все эти методы недостаточно эффективны. Эффективность орошения угольной пыли зимой из снежных пушек значительно меньше, чем из водяных летом, а химические составы, образующие корку на поверхности угля, бессильны при механическом воздействии на него, выполняя защитную функцию лишь против ветровых эрозий [3].

Так как перевалка угольной продукции в морских угольных портах в основном производится при помощи ленточных конвейеров и одним из главных источников пыления являются пересыпные станции, мы предлагаем аспирационное укрытие узла пересыпа конвейера (см. рис. 2).

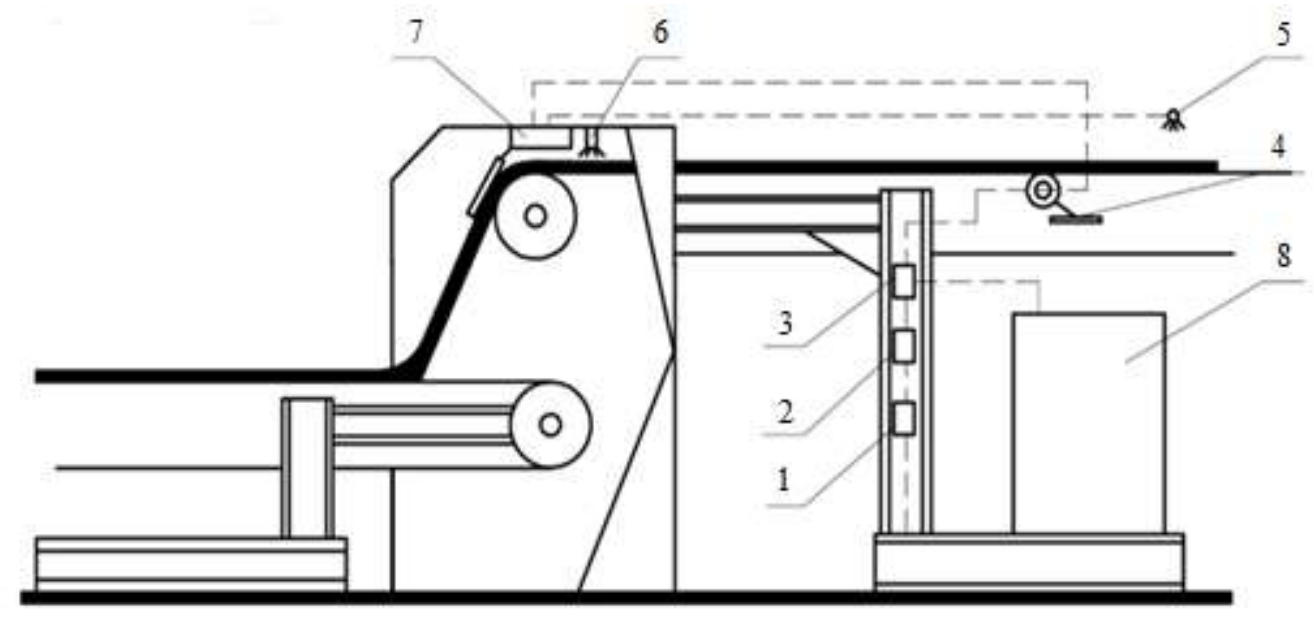

Рисунок 2. Аспирационное укрылте узла пересыпа конвейера

Способ, представленный на рисунке 2, включает увлажнение транспортируемой массы путем распыления жидкости через форсунки с помощью источника высокого давления. При этом дополнительно контролируют процесс перемещения транспортируемой массы с помощью контрольного устройства, расположенного под транспортерной лентой и включающегося при ее провисании под тяжестью транспортируемой массы, при срабатывании которого осуществляют орошение увлажняющей жидкостью транспортируемой массы угля. Кроме того, решение поставленной задачи достигается за счет того, что орошение транспортируемой массы после срабатывания контрольного устройства осуществляют путем подачи увлажняющей жидкости с помощью инжекторной установки на форсунки предварительного орошения, в свою очередь включение инжекторной установки осуществляют посредством открывания клапана с помощью шестеренного насоса. Дополнительно в процессе транспортировки производят увлажнение транспортируемой массы угля в местах пересыпа, для чего на конвейере в местах пересыпа устанавливают вертикальный клапан, с помощью которого осуществляют контроль поступления транспортируемой массы. Технический результат заключается в повышении автоматизации орошения транспортируемой массы на ленточных конвейерах и в зоне пересыпа [4].

Способ осуществляют следующим образом - подачу воды осуществляют из противопожарного става с добавлением концентрата эмульсии из бака 8. При перемещении транспортируемой массы по конвейерной ленте происходит небольшой провис ленты, и в момент провиса колесо 13 контрольного оросительного устройства 4 соприкасается с лентой и приходит в движение. При достижении определенной скорости колеса 13 внутри контрольного оросительного устройства 4 открывается клапан, после чего производят подачу смеси воды и эмульсии через регулятор расхода 2, фильтр 1 и инжекторную установку 3 на форсунку предварительного орошения 5. При подаче воды на инжекторную установку 3 в ней возникает давление разрежения и путем самовсаса концентрат эмульсии всасывается из бочки 8. Концентрацию эмульсии можно регулировать путем замены дроссельных заслонок в инжекторной установке 3. При достижении транспортируемой массы контрольного вертикального клапана 7 путем его срабатывания происходит подача воды или эмульсии на форсунку 6. Форсунка 6 орошает непосредственное место пересыпа. При отсутствии транспортируемой массы на конвейерной ленте не происходит соприкосновения последней с вертикальным клапаном и, таким образом, подача воды прекращается, что позволяет добиться автоматического орошения в зоне пересыпа угольной массы [4].

Контрольное оросительное устройство 4 является основным узлом автоматической системы пылеподавления. Общий вид контрольного оросительного устройства 4 показан на рисунке 3 . Установочный платик 12 контрольного оросительного устройства 4 устанавливается на раму ленточного конвейера. Установка производится таким образом, чтобы приводное колесо 13 касалось нагруженной транспортерной ленты и при движении ее вращалось. 


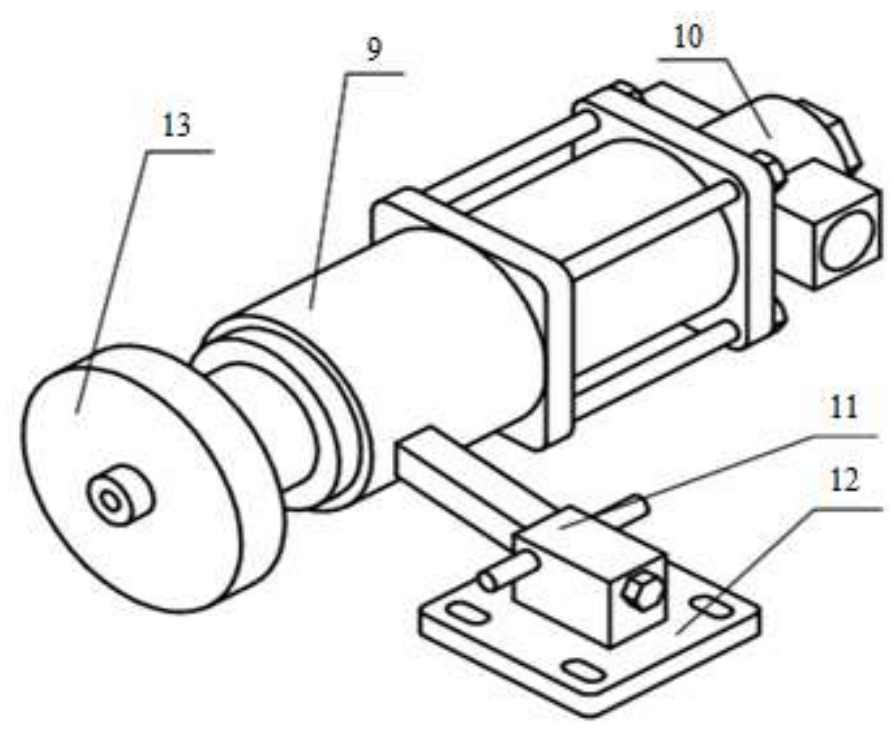

Рисунок 3. Контрольное оросительное устройство

Вращение приводного колеса 13 должно осуществляться в направлении по часовой стрелке. Регулировка силы прижатия колеса 13 к ленте осуществляется при помощи регулировочного болта, расположенного в месте соединения рычага 11 и платика 12. В корпусе 9 имеется встроенный шестеренный насос. Вращающееся приводное колесо приводит в действие шестеренный насос. Возникающее при работе насоса гидравлическое давление заставляет двигаться имеющийся внутри корпуса 9 поршень, который, в свою очередь, открывает клапан 10 , соединяя водяную магистраль с блоком форсунок 5, расположенным в зоне возникновения пыли [4].

Для обеспечения возможности отключения автоматической системы пылеподавления, а также для обеспечения возможности регулировки необходимого потока воды имеется регулятор расхода 2. Рукава высокого давления предназначены для соединения всех элементов системы между собой и подачи воды от водовода до блока форсунок.

Предлагаемая автоматическая система пылеподавления имеет следующие преимущества:

- простота изготовления;

- удобство транспортировки (все узлы транспортируются в сборе);

- простота установки;

- возможность автоматизировать процесс пылеподавления.

Можно сказать, что с помощью предлагаемого нами способа пылеподавления значительно снизится концентрация угольной пыли на ленточных конвейерах и в зоне пересыпа угольной массы. Это позволит улучшить условия труда на рабочих местах угольного терминала, а также снизит воздействие угольной пыли на окружающую природную среду.

\section{Список литературы}

1. Воздух рабочей зоны. Аэрозоли преимущественно фиброгенного действия. Общие принципы гигиенического контроля и оценки воздействия. ГОСТ Р 54578-2011. -М.: Стандартинформ, 2012 - 10с.

2. Охрана труда на предприятиях угольной промышленности / Голик А. С., Зубарева В. А.. - М.: Издательство Московского государственного горного университета, 2009. - 625 с.

3. Методы борьбы с угольной пылью [электронный ресурс] // URL: https://portnews.ru/projects/pub11/ (дата обращения: 03.05.2021).

4. Способ пылеподавления при транспортировке угольной массы // Патент РФ №2485321С2 / авторы и патентообладатели Копытин Д.В, Ильбактин Д. Ш., Толстыгин М.С., 2013.06.20, 3c.

\section{References}

(C) Кожевникова O.M., 2021

1. Vozdukh rabochey zony. Aerozoli preimushchestvenno fibrogennogo deystviya. Obshchiye printsipy gigiyenicheskogo kontrolya i otsenki vozdeystviya. GOST R 54578-2011. -M.: Standartinform, 2012 - 10p.

2. Okhrana truda na predpriyatiyakh ugol'noy promyshlennosti / Golik A. S., Zubareva V. A.. - M.: Izdatel'stvo Moskovskogo gosudarstvennogo gornogo universiteta, 2009. - $625 \mathrm{p}$.

3. Methods of dealing with coal dust [electronic resource] / / URL: https://portnews.ru/projects/pub11/ (date of the application: 03.05.2021). 
4. Method of dust suppression when transporting coal mass // RF patent №2485321C2 / authors and patent holders Kopytin D.V., Ilbaktin D. Sh., Tolstygin M.S., 2013.06.20,3p. 